\title{
Poetry After Kerch': Representing Jewish Mass Death in the Soviet Union ${ }^{1}$
}

\author{
Harriet Murav
}

Why was there no Holocaust in Soviet Russia?2 There were killings—approximately 2.5 million Jews died on Soviet soil-but the killings did not take on the same meaning as in the West, where the Holocaust emerged as a unique and paradigmatic set of events. ${ }^{3}$ Official Soviet history is part of the reason for the absence of the Holocaust in the former Soviet Union. Zvi Gitelman and Amir Weiner, among others historians, agree about the failure of Soviet historiography and commemoration to acknowledge the unique fate of Jews during World War II. In Bitter Legacy, Gitelman characterizes the dominant response to the Holocaust in Soviet historiography not as complete repression, but rather as a consequence of a universalist interpretation, according to which the destruction of the Jews was "part of a larger phenomenon ... a consequence of racist fascism." 4 Weiner's Making Sense of War traces the evolution of the Soviet version of the "Great Fatherland War" that made Jews disappear-both as soldiers and as Holocaust victims. ${ }^{5}$

The term "Holocaust" itself did not have broad currency in the West during the 1940s; it was not used in Russian publications until the Soviet Union collapsed in the 1990s, and I will therefore avoid it. Nonetheless, Soviet literature, almost completely neglected by scholars and critics, confronts the impossible history of the destruction of the Jews, but not in the same terms as Holocaust literature in the West. In the former Soviet Union and post-Soviet Russia, the scholarly and artistic response to the destruction of the Jews takes on its own, distinct outline, which combines the perspectives of Jewish victim, Jewish avenger, and Jewish victor. To trace these differences, this essay focuses on three Russian-language poems by Il'ia Sel'vinskii published during 
the 1940s. "Ia eto videl" (I Saw It), first published in January 1942, describes the poet's reaction to the sight of 7,000 corpses in a ditch outside the city of Kerch'. Each of the subsequent poems-"Sud $v$ Krasnodare" (The Trial in Krasnodar) and "Kandava" (Kandava, a city in Latvia) — returns to this scene.

The poems are among the earliest artistic responses in any language to the Nazi mass killings of Jews. ${ }^{6}$ They form a cohesive a narrative, building from murder to trial to commemoration. Sel'vinskii's writing confronts the impossible knowledge of what was not yet called the Holocaust even within the Soviet framework of the universality of the suffering that took place under German occupation. His poetry attempts to speak the pain of the victims, but at the same time sounds the call for revenge. Finally, a distinctly Jewish voice-that resonates with Soviet Yiddish literature-emerges in his work.

\section{The Ravine}

Il'ia Sel'vinskii (1899-1968) was born in Simferopol, attended gymnasium in Evpatoriia, and fought there during the Civil War. He rose to prominence in the 1920s, when he was associated with the literary movement known as "constructivism." One of his most well-known early works, "Uliaevshchina," describes an anti-Bolshevik uprising and includes an anarchist named "Shtein." A narrative poem about a gangster, titled "Mot'ka malkhamoves" (Mot'ka the Angel of Death, 1926), uses Yiddish and Hebrew expressions transliterated into the Russian text. In this regard his early writing resembles the work of Russian language Jewish writers of the time, including Isaac Babel', Eduard Bagritskii, Veniamin Kaverin, and Semen Gekht, who employed similar heterolinguistic devices in their work. During the Second World War, Sel'vinskii served in the army in Crimea, the Caucasus, and the Baltic front, and published with several army newspapers. He achieved the rank of colonel. ${ }^{7}$ His poem "Ia eto videl" (I Saw It) was first published in the newspaper Bol'shevik on January 23, 1942, reprinted on February 27, 1942 in the army newspaper Krasnaia zvezda (Red Star), and included in subsequent publications of his collected works. ${ }^{8}$ The poem has been available for decades; thousands and thousands of readers during the war, in the postwar period, and in the post-Soviet period have seen "I Saw It." But no one has recognized its relation to what became Holocaust literature in the West.

"Ia eto videl" concerns the murder of seven thousand Jews that took place just outside the Crimean city of Kerch' in 1941, in a place called Bagerovskii 
rov (ravine), which was used as an anti-tank ditch (a report of this episode was entered into the Nuremberg record by the Soviets). ${ }^{9}$ It is instructive to compare what Sel'vinskii wrote to the article that appeared in The New York Times on January 7, 1942. Titled "Molotoff Accuses Nazis of Atrocities", the article reported that "Soviet Foreign Commissar Vyacheslaff M. Molotoff ... charged that the Germans shot 8,000 in Kamenetz and Podolsk, 3,000 in Mariupol, several thousand in Kerch'."10 Molotov's description of the mass killing in Kiev conforms to the emerging Soviet narrative of the universality of suffering by identifying the victims as "Russians, Ukrainians, Jews," although he uses the qualifier "a large number" when referring to the Jews. ${ }^{11}$

Sel'vinskii wrote to his wife on January 12, 1942 that he "visited the ditch outside Kerch', where 7000 women, children, and old people lie shot to death ... And I saw them. I don't have the strength now to write about it in prose, my nerves have stopped reacting, what I could do, I expressed in verse." 12 The key phrase is "I saw them," which the poet uses both here in the letter and as the title of his poem. The Germans completed their bloody work in December of 1941; the Soviets retook Kerch' in January 1942, leaving the Germans no time to cover the evidence, as they did at Babii Iar. Indeed, the frozen bodies of the dead could be clearly seen.

The very opening stanza claims the role of the eyewitness as offering the most credible evidence of the mass murder:

You may ignore folk tales,

Doubt the newspaper,

But I saw it. With my own eyes.

Understand? I saw it myself.

Here's the road. And over there-hills.

Between them

Like this-

A ravine.

From this ravine grief rises.

Without limit.

No! you can't use words for this...

You have to howl! Scream!

Seven thousand shot dead in a frozen pit,

That turned red, like rust.

Who are these people? Soldiers? No.

Partisans, right? No. ${ }^{13}$ 
The first stanza raises the question of what kind of account is credible, discarding both "folk tales" (narodnye skazaniia) and newspaper reports (gazetnye stolbtsy) as susceptible to doubt, and offering as irrefutable the evidence of an eyewitness. The distinction between evidence that is not compelling and evidence that is carries with it an obligation on the part of the witness and those who hear his testimony. The opening words "mozhno ne slushat'," which I translate "you may ignore" can also be rendered more literally, "It is possible not to listen to," in the sense of hearken, attend to, obey. The opening line "mozhno ne slushat"' (you may ignore) contains an implied commandment, "nado slushat" (you must listen to): you must listen to this poem, because it speaks for the dead.

The "seven thousand shot dead in the frozen pit" have to be heard, and Sel'vinskii struggles to create an impossible language that could adequately translate the victims' pain:

К неумолимой грамматике сведен Каждый крик, слетающий с губ.

Здесь нужно бы... Нужно созвать бы вече, Из всех племен от древка до древка И взять от каждого все человечье, Все, прорвавшееся сквозь века,Вопли, хрипы, вздохи и стоны, Эхо нашествий, погромов, резни... Не это ль наречье муки бездонной Словам искомым сродни?
Every cry that flies from their lips Corresponds to an implacable grammar.

Here you would have to...call an assembly From every tribe

And extract from each all that is human, Everything that burst through the centuries, Shrieks, cries, sighs and groans, The echo of attacks, pogroms, butchery... Wouldn't this

Utterance

Of bottomless torment

Be equal to the word that is sought? ${ }^{14}$

Sel'vinskii imagines an impossible language that has no words, but only inchoate cries. Each cry nonetheless corresponds to an "implacable grammar," the grammar of pain, which has no grammar, which destroys articulate speech. ${ }^{15}$ To speak this language properly is to submit to torment, to be reduced to what is less than human. Each "correct" utterance brings the speaker closer to death. To conform to this implacable grammar means to cease speaking. Kerch' thus creates an impossible poetics.

This question of impossibility has broad resonance in the critical reception of Holocaust literature. Not only Adorno, whose essay I hint at in my ti- 
tle, but also Lyotard, Derrida, Cathy Caruth, and others address the problem of impossibility in relation to the Holocaust: the impossibility of poetry itself, and the impossibility of traumatic knowledge. ${ }^{16}$ Lyotard in The Differend and Derrida in his writing on Paul Celan, focus on the impossibility of testimony and witnessing. ${ }^{17}$ The differend is "the unstable state and instance of language wherein something must be able to be put into phrases yet cannot be." ${ }^{18}$ Sel'vinskii's "I Saw It," which could easily be dismissed as mere Soviet propaganda, engages one of the central issues of Western writing about the Holocaust.

The victims, whose pain the poet translates into an impossible language, must then be listened to, and obeyed, as in the eighth stanza, in which the dead command the poet:

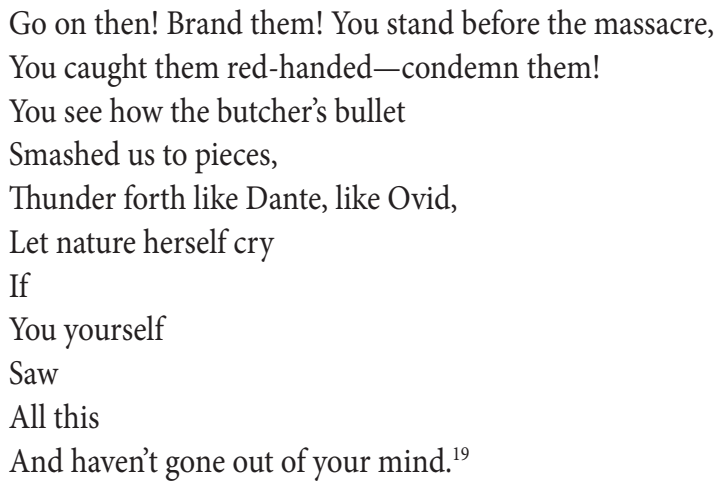

The first stanza, with its delineation of what does not have to be "listened to" anticipates this order from the dead.

In three succeeding stanzas Sel'vinskii picks out details describing three different victims of the mass murder: a young man (paren') with an amputed leg; a peasant woman (babka), a Christian, who reproaches the Virgin Mary for what the Germans have done; and a Jewish woman with her child (isterzannaia evreika/ pri nei rebenok). The mention of the Christian conforms to the Soviet cliché of the universality of suffering during the German occupation. Sel'vinskii also lists as victims the inhabitants of the surrounding collective farms, whose population included a significant number of Jews. ${ }^{20}$ Sel'vinskii, who grew up in Crimea, knew who his neighbors were. The mention of the amputee is not misleading: the Nazis had a policy of exterminating the disabled. 
The description of the Jewish mother and child is the longest and most emotional:

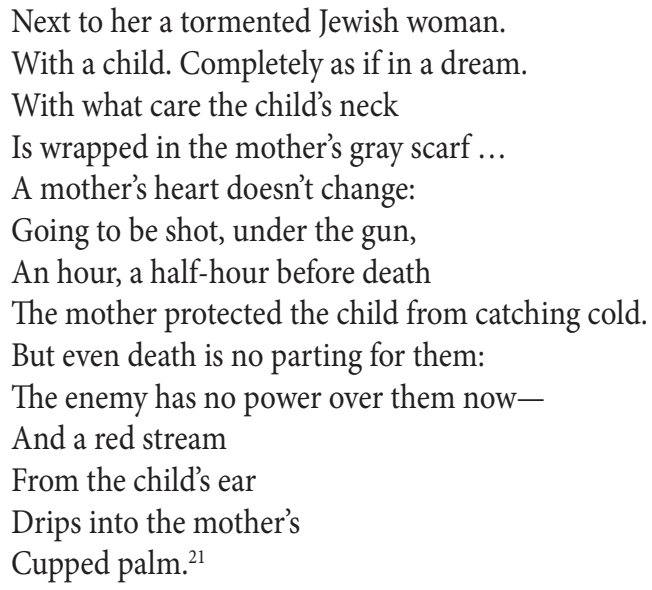

This description of the passive Jewish mother dramatically changes in a subsequent stanza when the poet declares that the mother's hands, now a fist, will "burn through" the Germans' "blue waltzes." The image of the Jewish mother's fist transforms Jewish suffering into Jewish revenge, an important dimension of the Soviet-Jewish response to the Nazi genocide. Sel'vinskii develops the theme of revenge both in "I Saw It" and in subsequent poems.

"I Saw It" does not name its implied narrator as a Jew; nor does it explicitly identify the seven thousand corpses in the ravine as Jews, except in the vignette of the Jewish mother. Sel'vinskii's fellow Soviets, however, knew who the victims were. The mention of the Jewish mother would have been more than enough; even had Sel'vinskii used only the Soviet code for Jewish victim, "peaceful Soviet citizen," his readers would have understood. His Western readers, however, could use the absence of explicit naming to characterize the poem as too Soviet and not Jewish enough. Sel'vinskii addresses this issue in the poem I discuss next.

\section{No Mercy}

Sel'vinskii returns to the mass killing at Kerch' in a later poem, "Sud v Krasnodare" (The Trial at Krasnodar), first published in the literary journal Znamia in 1945 and republished in an anthology of the author's work in $1947 .{ }^{22}$ The poem describes the first war crimes trial conducted by a Soviet 
military tribunal in Krasnodar from July 14 to July 17, 1943. The Germans had occupied the North Caucasus Krasnodar region in the latter part of 1942. They and their collaborators killed approximately 20,000 Jews, many of whom were evacuees from Ukraine..$^{23}$ Three hundred patients at a psychiatric hospital, and at least 80 wounded Soviet officers were also killed; Jews were included in these numbers. The Germans introduced mobile gas vans, known in Russian as dushegubki, in these locations. I. I. Kotov, who survived a gas van killing, gave key testimony at the trial. In the poem, one of the defendants accused of collaborating with the Gestapo attempts to exonerate himself by saying that he only worked for the Germans as a driver, without killing anyone. Turning on the ignition of a dushegubka was what released the gas into the chamber of the vehicle. Kotov identifies him as the driver of a mobile gas van (dushegubka):

\author{
But Kotov's two moonbeam eyes \\ stared with such force \\ at the witness, \\ that it seemed for a moment \\ two shadows fell on the floor from them ... \\ And his voice in the hysterical quiet \\ of the tormented hall pronounced these words: \\ -I was in the fourth group, driver. \\ Don't you recognize my ghost? ${ }^{24}$
}

This defendant and seven others were sentenced to death; approximately 30,000 people came to view the hangings. ${ }^{25}$

The poem contrasts different responses to the verdict. A newspaper correspondent asks the first-person narrator, the poet, whether he feels pity for the condemned; the poet does not. The correspondent, skeptical about the poet's denial, characterizes it as mere propaganda ("Etot vash otvet/ sovsem ne bolee, kak propaganda"). For the poet, however, the sight of victims' bodies at Kerch' - "seven thousand corpses" (sem' tysiach trupov) - is the basis for his lack of pity for the collaborators. In the earlier poem, "I Saw It," Sel'vinskii wrote: "Whoever saw you, from now on/ Will carry your wounds in his soul" (Kto vas uvidel, otnyne naveki/ Vse vashi rany v dushe uneset). ${ }^{26}$

The wound makes itself felt in "Sud $v$ Krasnodare" and even earlier; from the wound comes the poem "I Saw It." Note the relation between "Whoever saw you," and "I saw it." Earlier I remarked on the emphasis on seeing as 
the grounds for the poet's credibility, as if the line "I saw it" was marked "I saw it (Ia eto videl);" now another accentuation emerges- "I saw it" (Ia eto videl). It was I who saw it, and therefore I am marked, wounded by it, the victims' pain inscribes itself in me, I am implicated in it, I must answer it, I belong again and already to this community. There is something like the Deuteronomic circumcision of the heart playing just under the surface of the poem ("Circumcise the foreskin of your heart," Deut. 10:16; "And the Lord your God will circumcise your heart and the heart of your offspring" Deut. 30:6). I saw it and have been circumcised in my heart, I now carry your wound and therefore cannot and must not feel pity for the perpetrators.

As an eyewitness to the aftermath of the mass killing of Jews, he cannot feel sorrow for anyone who aided in other, similar killings. The exchange that follows explicitly links religious affiliation and the emotional response to the verdict. The poet's interlocutor, the correspondent, tells him that as a Christian he is obliged to pity the condemned: "Kak khristianin, ia dolzhen pozhalet' seichas vot etikh." The poet's extraordinary response, with which the poem ends, is worth quoting in full:

$\begin{array}{ll}\text { Немыслимая боль, как от удара, } & \text { An unthinkable pain } \\ \text { на миг оборвала мое дыханье- } & \text { stopped my breath } \\ \text { и тошнотой под горло.... } & \text { nausea filled my throat ... } \\ \quad \text {-Уходите! } & \text { Get out! } \\ \text { 'Христианин' опешил. } & \text { The “Christian” was taken aback. } \\ \quad \text {-У -хо -ди -те! } & \text { Get out! } \\ \text { Благодарите бога, что никто } & \text { Thank God no one } \\ \text { не слышал этой фразы. } & \text { heard that phrase. } \\ \quad \text { Ну! } & \text { Get moving! } \\ \text { Ступайте! } & \\ \text { Мне очень жалко вашего Христа. } & \text { I am very sorry for your Christ. }\end{array}$

The poet names his interlocutor as a Christian in the line- "The 'Christian' was taken aback" - and by implied contrast, names himself as a non-Christian. He goes on to express the pity the correspondent sought for the condemned collaborators for Christ instead: "I am very sorry for your Christ." Note the possessive adjective "your." This line about pity for "your Christ" can be parsed as a Jewish response, a way that the poet names himself as a Jew. It can also be parsed as a Soviet, atheist response to the demand for Christian compassion; however, Sel'vinskii does not mention Russia, the Soviet Union, 
Stalin, or communism in the passage above, just the contrast between the Christian and the non-Christian. ${ }^{28}$ The rejection of Christ and the rejection of mercy for the perpetrators are equally Soviet and Jewish responses to the mass killings of victims whom the Soviets did not identify as Jews.

The poet's fury at the demand for Christian compassion represents one of the dimensions of the Soviet-Jewish response to the Nazi genocide. SovietJewish works written in the 1940s and in subsequent periods emphasize rage and the desire for retribution, in contrast to what emerged as Holocaust literature in the West. The last stanza of Sel'vinskii's "I Saw It" hammers away at the theme of retribution:

Ров... Поэмой ли скажешь о нем?

Семь тысяч трупов.

Семиты... Славяне...

Да! Об этом нельзя словами.

Огнем! Только огнем!
The ravine..? Can you describe this in a poem?

Seven thousand corpses.

Semites...Slavs

Yes! Not with words,

But with firepower. ${ }^{29}$

The only language adequate to speak of the mass killing is the language of revenge. Revenge, "nekome," is the central motif of Soviet Yiddish literature written during the war. A document produced by the Jewish Anti-Fascist Committee on the occasion of a rally held on August 24, 1941 appealed to "fellow Jews the world over" to join the Soviet people's and the Red Army's "holy war" against Hitler: "it is not by memorial candles but by fire that the murderers of humanity must be destroyed, [n] ot tears, but hate and resistance to the monsters." ${ }^{30}$ Peretz Markish's 1943 "Dem yidishn shlaktman" (To the Jewish Warrior) transforms the pain of the victims into a call for revenge: "Un blut af ale vegn shrayt: nekome!" (The blood on every road cries out: revenge!). ${ }^{31}$

Itsik Fefer's "Di shvue" (The Oath) was published in 1942 in the first issue of the Soviet Yiddish newspaper Eynikayt, the organ of the Jewish Antifascist Committee, and published in Russian under the title "Kliatva" (The Oath) in the mainstream literary journal Znamia (The Banner) in the same year. The poet swears that his hatred and wrath will not be spent until he feels his enemy's blood on his own flesh, and vows to fight on even if he loses both arms and grows blind. Fefer's "Oath" works by building from the consequences of his own oath and vow: the speaker swears that if he loses one arm, he will kill the enemy with the other, if he loses his other arm, his hate will give him 
strength to continue fighting. If he fails to erase every trace of the enemy and obliterate the memory of his enemy, if he fails in his oath and vow to the Soviet land and the Jewish people, his own name will remain forever on the roll-call of shame. ${ }^{32}$

The source of the revenge motif is Psalm 137, which begins, "By the rivers of Babylon, there we sat down, yea, we wept when we remembered Zion." The historical event around which the psalm is built is the destruction of Jerusalem in $586 \mathrm{BCE}$, and the subsequent Babylonian captivity-the first in a series of catastrophic destructions in Jewish history, that, according to traditional Jews, culminates in "der driter khurbn" (the third destruction), what the Soviets did not call the Holocaust. In the psalm, the captors demand that their prisoners sing to them; the Jews' response, however, turns compliance into resistance. The psalm begins in uncertainty, "How shall we sing the Lord's song in a foreign land?" and moves to action, first with an oath of remembrance- "If I forget thee, O Jerusalem, let my right hand forget her cunning./ Let my tongue cleave to the roof of my mouth, if I remember thee not"-and culminates in a prophecy of Babylon's destruction, depicting in grisly terms the joy of revenge: "O daughter of Babylon, that art to be destroyed; happy shall he be that repayeth thee as thou has served us./ Happy shall he be that taketh and dasheth thy little ones against the rock." The stanza is structured around a promise made by the poet and the enumeration of the consequences of its violation.

It is not only revenge that links Sel'vinskii's writing to the work of Soviet Yiddish poets. His explicit lack of "Christian" compassion for the fate of the perpetrators is another theme that connects him to the Yiddish writers. Bergelson's story It Was Night and Became Day (Geven iz nakht un gevorn iz tog), published in 1943, explicitly reserves compassion (mitleyd) for Jewish victims and not German perpetrators. ${ }^{33}$ Itsik Kipnis's Yiddish language memoir Fun mayne togbikher, published in Sovetish heymland in 1965, describes his reaction to the hanging of convicted German war criminals in Kiev in 1946 as unmitigated joy. His "heart sang": "Un in mir hot gezungen ...un in mir zingt, s'tantst unter mir." ${ }^{34}$ In the West, in contrast, Jewish rage was suppressed. Naomi Seidman's comparison of the Yiddish, French, and English versions of Eli Wiesel's Night reveals that the original Yiddish emphasizes the theme of revenge. The original Yiddish reproaches the survivors for failing to carry out revenge; the subsequent translations into French and English praise them for transcending revenge. ${ }^{35}$ 
Where did Jewish revenge go, in what ways was it displaced and concealed in the West? This question goes beyond the confines of this paper; however, the differences between Western and Soviet (and Soviet Jewish) narratives of the Nazi genocide shed light on why Soviet Jewish responses to the destruction of the Jews remain illegible as Holocaust literature. Saul Friedlander describes the outlines of the Western Holocaust narrative in terms of passivity and heroism, catastrophe and redemption. Most Jews were led like sheep to the slaughter; the heroic few ghetto fighters and partisans mostly belonged to Zionist youth movements. The Soviet war narrative also casts the Jews of capitalist Western Europe as victims. The starring role, however, is reserved for the victorious Red Army, which united the peoples of the USSR, including Jews, Ukrainians, and others, and most heroically, Russians. The Soviet Union saved Europe from Hitler. "Implicitly, the catastrophe of European Jews," Friedlander observes, with regard to the Western narrative, "is linked to the redemption of Israel." ${ }^{36}$ In the West, the Jewish vow, as in Fefer's "Shvue," went into the cry "Never again," into the struggle for Israel, struggle, which, after 1948, the Soviet Union viciously opposed, another reason that nothing written there could be seen as Jewish, or, proJewish.

Quentin Tarantino's 2009 film Inglourious Basterds raises the specter of Jewish revenge in fantasy celluloid form. The "face of Jewish revenge" is self-conscious simulacrum, a projection on a projection, played on hundreds of movie screens. ${ }^{37}$ The call for Jewish revenge in the Soviet Union in the 1940s, in contrast, was-dare I say it-real. Western readers brought up on the image of Jews as victims cannot recognize the work of Sel'vinskii, Fefer, Markish, Bergelson, and others as Holocaust literature because the theme of revenge is too vivid and too visceral to conform to expectations of Jewish suffering.

\section{A Double Dream}

"Kandava" (the title is the name of a city in Latvia) is the final and most important of the triad of poems written by Sel'vinskii in the 1940s in response to the destruction of the Jews. In this work, published in 1947, the poet describes himself both as a Jewish victim of the Nazi genocide and also as a triumphant Soviet and Jewish army officer accepting the German surrender at Kandava. Sel'vinskii in fact participated in the ceremony in May 1945 as a 
Soviet officer ${ }^{38}$ The poem, remarkably, frames its account of military triumph with the Jewish nightmare of the death camp:

Мне снился накануне сон: иду с женою рядом где-то в Освенциме

или в Майданеке. Иду аллеей фашистских серо голубых солдати тысячи оледенелых глаз, презрительных, насмешливых, злорадных, а то и просто любопытных-смотрят на то, как мы идем на гибель.
Last night I had a dream: I was walking with my wife somewhere either

in Auschwitz

or Majdanek. I was walking past a row of blue-gray fascist soldiersand myriads of hateful eyes contemptuous, mocking, malicious and sometimes just curious-watched how we went to our death. ${ }^{39}$

The opening stanza poses the question of the relation between the death camps and Kandava, the title of the work. The stanza that follows, however, does not answer the question, but introduces yet another location, the scene of the poet's childhood. The poet remembers himself as a little boy, trying to see how long he could hold his breath; this section ends with a philosophical reflection with the real suffering that dreams can inflict. The first part of the poem concludes:

Так если есть “пейзаж души” где можно бы его изобразить,отметьте на моей: “Майданек.”
If there is a "landscape of the soul" and a map, on which you could draw itmark on mine: "Majdanek."40

The repetition of the sounds "m" plus "e" in "otmet'e," "moei" and the first syllable of Majdanek (which I have tried to capture with "mark," "mine," and "Majdanek") embody what Roman Jakobson calls paronomasia, sound mirroring. ${ }^{41}$ The reflection of the sound of the previous word in the succeeding syllables impedes the forward motion of the line; the sound-image that is thereby formed serves to fix the place of the poet's nightmare as the death camp, pinning him down to this spot on the map and no other. The poet does not name himself as a Jew, and he never claims first-hand knowledge of Auschwitz, Majdanek, or Treblinka, all of which he mentions in the poem. However, he explicitly contrasts his own map of nightmares with that of some dreamer for whom the nightmare would take place in 
some other location; some other dreamer would dream of being chased by a panther in the jungle. In labeling his own space on the map of nightmares with the name of a death camp, Sel'vinskii signals his belonging among murdered Jews.

The second part of the poem dramatically changes register from dream and memory to documentary detail, giving the precise date and place, and specifying the division of the German army that surrendered. As I mentioned earlier, this section of the poem reflects Sel'vinskii's real-life experience as a Soviet officer. The poet identifies himself one of "seven Soviet officers" who enter the base to accept the surrender. The nightmare of Majdanek and other scenes of the mass killing of Jews disrupt the victory at Kandava. As he walks in front of the ranks of Germans, the poet remembers his nightmare of the previous evening and recognizes the same look of contempt in the eyes of the defeated soldiers. A German captain in particular draws his attention, because he wears a little bronze badge on his sleeve depicting the most beloved places of the poet's youth in a now destroyed Crimea. One place stands out:

И, наконец, от древности седая, заваленная пеплом, как Помпея, забрызганная кровью и мозгами вершина всех моих мучений-“Керчь”!
And finally, gray with age, covered in ash, like Pompei, spattered with blood and brains the height of all my torments- "Kerch"'!42

The mass killing at Kerch'- the subject of his poem "I Saw It" - which took place only three years earlier, is thrust back from the recent to the remote past; covered with ash like Pompei, it impossibly belongs simultaneously to antiquity and to the immediate present. It is covered with ash but still gory with blood and brains. Kerch' happened in the ancient past and it is still happening now. The delay in coming to terms with it and the repetition of its immediacy are characteristic of the belatedness of trauma. The poet tears the badge from the German officer's sleeve, and thinks the captain must be dreaming his, the poet's dream, from the night before-the poet's dream of Auschwitz or Majdanek, in which he and his wife were Jewish victims and the Germans were triumphant. ${ }^{43}$ The captain must be dreaming that one of his prisoners dared to assault him, "an S. S. officer, an Aryan." 
But on the day of his own surrender, however, the German does not respond to the Jew's act. He keeps quiet. The poem ends by describing what can be heard in that silence:

А в этом яростном молчаньи

я слышал шум красноармейских стягов, браваду труб и грохот барабанов,

и ликованье мертвых голосов из пепла, из поэм, из сновидений!
And in that vivid silence I heard Red Army banners The blare of the trumpets and the din of drums, and the exultation of dead voices made of ash, poems, and dreams! $!^{44}$

The last lines of the poem bring together the incommensurable elements of the interior space of the poet's nightmare, the voices of death camp inmates turned to ash, the triumphant sounds of victory, and poetry itself, without subordinating any one voice to another. It is important that the victory of the Soviet Army-the victory of Soviet Jews-does not drown out the voices of the Jewish dead.

I conclude my discussion of "Kandava" by returning to the issues that I raised in the beginning of this chapter. Far from making Jews disappear as soldiers or as Holocaust victims, as Amir Weiner contends, "Kandava" makes Jews vividly legible in both roles. "Memory of the Jewish catastrophe," to use Weiner's language, is not submerged in the grand narrative of the universality of Soviet suffering. ${ }^{45}$ The Jewish catastrophe escapes temporal boundaries in the poem "Kandava": it is a historically and impossibly part of the poet's childhood terror and is as ancient as the disaster at Pompei; it disrupts the poet's triumph at the place called Kandava. The poem's multiple embedded narratives of adult nightmare and "torment," childhood terror and victory, suspend the linear, teleological motion towards a single message of Soviet triumph. The poetic use of mise-en-abyme, the placement of the image of the death camp both as the frame for and at the center of the narrative of victory at Kandava, makes it impossible to decide which narrative dominates. It is this undecidability that is so crucially a part of the distinctly Soviet but nonetheless universally impossible history of what Sel'vinskii does not call the Holocaust. 


\section{Notes}

1 Another version of a section of this essay was originally published in Harriet Murav, Music from a Speeding Train: Jewish Literature in Post-Revolution Russia (Stanford, Stanford University Press, 2011), 154-166. I am grateful to Stanford University Press for granting me permission to use this material.

2 For a discussion, see David Shneer, Through Soviet Jewish Eyes: Photography, War, and the Holocaust (New Brunswick, NJ: Rutgers University Press, 2011).

3 Zvi Gitelman, "Soviet Jewry before the Holocaust," in Bitter Legacy: Confronting the Holocaust in the USSR, ed. Zvi Gitelman (Bloomington: Indiana University Press, 1997), 11.

4 Zvi Gitelman, "Politics and the Historiography of the Holocaust in the Soviet Union," in Bitter Legacy: Confronting the Holocaust in the USSR, ed. Zvi Gitelman (Bloomington: Indiana University Press, 1997), 18.

5 Amir Weiner, Making Sense of War: The Second World War and the Fate of the Bolshevik Revolution (Princeton: Princeton University Press, 2001), 191-235.

6 For a book-length study of Sel'vinskii and "Ia eto videl," see Maxim Shrayer, I SAW IT: Ilya Selvinsky and the Legacy of Bearing Witness to the Shoah (Boston: Academic Studies Press, 2013).

7 I take my account of Sel'vinskii's biography from Elektronnaia evreiskaia entsiklopediia, s.v. "Sel'vinskii, Il'ia," http://www.eleven.co.il/article/13753 (accessed December 15, 2011); L. M. Farber, "Sel'vinskii," in Kratkaia literaturnaia entsiklopediia, vol. 6, ed. A. A. Surkov (Moscow: Sovetskaia entsklopediia, 1971); and Ts. Voskresenskaia, "Na voine: iz dnevnikov i pisem rodnym 1941-1945gg." Novyi mir 12 (1984): 163-75.

8 The edition published in Krasnaia zvezda speaks of "Russian grief” ("russkoe gore"); subsequent reworkings in 1964 and 1971 omit this phrase and introduce other variations. I use the version found in Il'ia Sel'vinskii, Sobranie sochinenii v shesti tomakh, vol. 1 (Moscow: Khudozhestvennaia literatura, 1971). Unless otherwise noted, all translations from this and other works are my own.

9 Catherine Merridale characterizes the mass killing at Kerch' as providing the first evidence of the German policy of such killings; see Merridale, Ivan's War: Life and Death in the Red Army, 1939-1945 (New York: Metropolitan Books, 2006), 291. For other discussions of the Kerch' mass killing, see Il'ia Al'tman, Zhertvy nenavisti: Kholokost v SSSR 1941-1945 (Moscow: Fond “Kovcheg," 2002), 287; Yitzhak Arad, ed., Unichtozhenie evreev SSSR v gody nemetskoi okkupatsii, 1941-1944: sbornik dokumentov i materialov (Jerusalem: Yad Vashem, 1992), 183-85; and Yitzhak Arad, The Holocaust in the Soviet Union (Jerusalem: Yad Vashem, 2009), 402-3.

10 "Molotoff Accuses Nazis of Atrocities: Note Detailing 'Crimes' Handed to All Foreign Diplomats," New York Times, 7 January 1942, 8.

11 Ibid. Photographs of the Kerch' mass killing, captioned "Hitlerite Atrocities at Kerch'," were sent to Britain from Moscow. See Janina Struk, Photographing the Holocaust: Interpretations of the Evidence (London: I. B. Tauris, 2004), 47.

12 Sel'vinskii, Sobranie sochinenii, vol. 1, 678. For a discussion of the photograph that accompanied the poem, see David Shneer's essay in this volume. 
Ibid., 352.

Ibid., 355

15 For a discussion of pain and language see Elaine Scarry, The Body in Pain: The Making and Unmaking of the World (New York: Oxford University Press, 1985), 42-45, 60-61. Cathy Caruth, Unclaimed Experience: Trauma, Narrative, and History (Baltimore, MD: Johns Hopkins University Press, 1996).

17 See, for example, Jacques Derrida, Sovereignties in Question: The Poetics of Paul Celan, ed. J. D. Caputo (New York: Fordham University Press, 2005), 65-96; Sidra DeKoven Ezrahi, "Representing Auschwitz," in The Holocaust: Theoretical Readings, ed. Neil Levy and Michael Rothberg (New Brunswick: Rutgers University Press, 2003), 31822; and Jean-Francois Lyotard, The Differend: Phrases in Dispute, trans. Georges Van Den Abbeele, Theory and History of Literature, no. 46 (Minneapolis: University of Minnesota Press, 1988).

18 Lyotard, Differend, 9.

19 Sel'vinskii, Sobranie sochinenii, vol. 1,354.

20 Jewish agricultural settlement in this region began in Tsarist times and continued in the 1920s and '30s. See Jonathan Dekel-Chen, Farming the Red Land: Jewish Agricultural Colonization and Local Soviet Power, 1924-1941 (New Haven: Yale University Press, 2005).

Il'ia Sel'vinskii, "Sud v Krasnodare," Znamia (1945): 11. I take the text from Il'ia Sel'vinskii, Krym, Kavkaz, Kuban' (Moscow: Sovetskii pisatel', 1947), 147-55.

For a discussion of this and other Soviet war crimes trials, see Ilya Bourtman, "Blood for Blood, Death for Death': The Soviet Military Tribunal in Krasnodar, 1943," Holocaust and Genocide Studies 22.2 (Fall 2008): 246-65; and Alexander Victor Prusin, "Fascist Criminals to the Gallows!': The Holocaust and Soviet War Crimes Trials, December 1945- February 1946," Holocaust and Genocide Studies 17.1 (Spring 2003): 1-30.

Sel'vinskii, Sobranie sochinenii, vol. 1, 355.

The visceral revulsion that arises in response to the demand for compassion is an important factor in resolving the question. In his study of nationalism, Benedict Anderson writes that people do not as a rule go to their deaths for the sake of an abstract idea, but rather, for the sake of a people with whom they identify; see Benedict Anderson, Imagined Communities: Reflections on the Origin and Spread of Nationalism (London and New York: Verso, 1991), 1-7. By the same logic, the poet's nausea stems not from his allegiance to communist atheism, but rather, from his horror and pain at the sight of the corpses outside Kerch'. These emotions, we may assume, flow both from his humanity and his particular affiliation as a Jew. However, identification with the Jews and identification with the Soviet Union do not preclude one another. The poet's sense of loyalty to the Soviet Union in the 1940s, expressed in this and other poems, arises, it can be argued, from his position as a Jew. The Soviet Union, as a non- 
Christian nation, removed the disabilities that burdened Jews in the Tsarist period. The Nazis made antisemitism the cornerstone of their state ideology.

Sel'vinskii, Sobranie sochinenii, vol. 1, 355.

"An Appeal to World Jewry," in War, Holocaust and Stalinism: A Documented Study of the Jewish Anti-Fascist Committee in the USSR, ed. Shimon Redlich ([New York]: Harwood Academic Publishers, 1995), 175.

Peretz Markish, Heymland: Literarishe zamlbukh (Moscow: Der emes, 1943), 3. David Shneer explicates the link between the theme of blood and revenge in "Rivers of Blood: Peretz Markish, the Holocaust, and Jewish Vengeance," in A Captive of the Dawn: The Life and Work of Peretz Markish, ed. Joseph Sherman et al. (Oxford: Legenda, 2011), 145.

Itsik Fefer, Roytarmeyish (New York: ICUF, 1943), 3.

David Bergelson, Geven iz nakht un gevorn iz tog. (Moscow: Der emes, 1943).

Itsik Kipnis, "Fun mayne togbikher," Sovetish heymland 1 (January 1965): 117.

According to Seidman, the Yiddish Un di velt hot geshvign describes a scene in which surviving young men go to Weimar to steal food and clothing and to "rape German girls," but the narrator indicts them for their failure to fulfill "the historical commandment of revenge" (Naomi Seidman, Faithful Rendering: Jewish Christian Difference and the Politics of Translation [Chicago: University of Chicago Press, 2006], 221). Seidman does not specify a textual source for this commandment, but a good candidate is Psalm 137.

Saul Friedlander, “The Shoah Between Memory and History”, in Breaking Crystal: Writing and Memory After Auschwitz, ed. Efraim Sicher (Urbana: University of Illinois Press, 1998), 347.

For a discussion of the debate surrounding the film, see Ben Walters, "Debating Inglourious Basterds," Film Quarterly 63.2 (2009): 19-21.

For an overview of Sel'vinskii's participation in the war and a selection of his letters and diary entries from this time, see Voskresenskaia, "Na voine."

Sel'vinskii, Krym, 209.

Ibid., 211.

Roman Jakobson, Language in Literature, ed. Krystyna Pomorska and Stephen Rudy (Cambridge, MA: Harvard University Press, 1987), 86.

Sel'vinskii, Krym, 215-16.

In this respect "Kandava" reworks the motif of the double dream from Lermontov's "Son.” See M. Iu. Lermontov, Izbrannye proizvedeniia v dvukh tomakh, vol. 1 (Moscow: Khudozhestvennaia literatura, 1963), 306. I am grateful to Valeriia Sobol for pointing out this similarity.

Sel'vinskii, Krym, 217.

Weiner, Making Sense of War, 191-235. 